\title{
DRUGS AND FATAL TRAFFIC ACCIDENTS IN THE CZECH REPUBLIC
}

\author{
Viktor Mravčík ${ }^{1}$, František Vorel ${ }^{2}$, Tomáš Zábranský ${ }^{3}$ \\ ${ }^{1}$ Czech National Monitoring Centre for Drugs and Drug Addiction, Prague, Czech Republic \\ ${ }^{2}$ Forensic Medicine Department, Hospital, České Budějovice, Czech Republic \\ ${ }^{3}$ Center for Addictology, Psychiatric Clinic of the 1st Medical Faculty and Faculty Hospital, Charles University in Prague, Czech Republic
}

\begin{abstract}
SUMMARY
Introduction: The aim of the study was to determine the prevalence of psychotropic drug use in active participants in traffic accidents who died during the accident or shortly after it due to injuries resulting from the accident.

Methods: A special mortality register containing data of all forensic autopsies was analysed. The studied sample consisted of persons who died during traffic accidents and were active participants in those ones (pedestrians, cyclists, or drivers), and were toxicologically tested during the forensic examination.

Results: The sample consisted of 1,213 cases, 1,039 (85.7\%) males and 174 (14.3\%) females who died in 2003-2005. Ethanol was found in $34.7 \%$ of cases, however a significant declining trend over the years was noted. The proportion of positive detections for any psychotropic drug other than alcohol was 7.2\%; benzodiazepines were found most frequently (3.6\%), followed by cannabis (2.2\%), and stimulants (1.7\% of the sample). Positive findings of ethanol were significantly more common among males, whereas positive benzodiazepine tests were more frequent in females. Positive cases were significantly younger than negative ones for ethanol, volatile substances, stimulants, and cannabis; in cases of positive medicaments tests, the positive cases were significantly older than the negatives.
\end{abstract}

Key words: drugs and alcohol use, forensic medicine, traffic accidents, driving under the influence

Address for correspondence: V. Mravčík, National Centre for Drugs and Drug Addiction Office of the Governement, Nábreží E. Beneše 4, 11801 Praha 1 - Malá Strana, Czech Republic. E-mail: mravcik.viktor@vlada.cz

\section{INTRODUCTION}

The use of psychotropic drugs - both legal and illegal - is an important factor influencing the safety of road traffic. The most important consequences of decreased road-traffic safety are accidents, particularly fatal ones i.e. those involving deaths.

The relationship between the use of psychotropic drugs and road traffic is complex and multifaceted. Nevertheless, the major attention of both public and experts is focused on impaired driving. Different psychotropic drugs in different doses have different impacts on driving. Forensic and practical difficulties arise when it comes to the detection of drugs in drivers especially if a forensic expert is required to ascertain the level of active metabolites in body fluids and to estimate related driving impairment.

Alcohol can impair driving ability even in low levels and there is no evidence of any threshold under which the influence of alcohol on road traffic safety would be negligible - alcohol increases both the risk of traffic accidents and the severity of injuries. The effect of other drugs is less well studied, particularly due to practical difficulties in the detection of the levels in body fluids (1-3). However, an impairing effect has been described on driving performance for cannabis, ecstasy (MDMA), antidepressants (esp. benzodiazepines) and other drugs in a substantial number of studies (4, 5, 6-12). Even if there is a well described different behavioral effect of different drugs that is moderating their direct influence on human motor functions (e.g., whereas alcohol and stimulants increase the propensity to engage in risky behavior while driving, cannabis seems to work in the opposite direction), there is general consensus in the public health and road safety experts that the consumption of any psychotropic substance poses an avoidable risk for road traffic and as such should be outlawed or at least punished by severe administrative sanctions (13).

Lifetime prevalence of driving under the influence of alcohol is approximately $20 \%$ globally (14). Lifetime prevalence of driving under the influence of other drugs (illegal or pharmaceutical) is $1-5 \%$ in developed countries (5). Last year's prevalence was reported to be $3-4 \%$ in the same countries (15). In parallel with its highest prevalence in the general population, the most prevalent illegal drug in drivers is cannabis; far lower prevalence is described for opioids, cocaine and amphetamines (16). Young adults, especially men, report driving under the influence of drugs more frequently e.g., $15.1 \%$ of senior students reported driving under the influence of cannabis in the past year in Canada (17). An exceedingly high prevalence of drug driving has been observed in recreational and regular drug users $-35 \%$ of party goers drove under the influence of drugs at least once in their life in Scotland (18). Impaired driving in problem drug users or drug addicts is even more prevalent $(19,20)$. In a recent large-sample Czech 
study, lifetime prevalence of driving under the influence was reported by $37 \%$ of surveyed party-goers for cannabis, $28 \%$ for alcohol, $17 \%$ for ecstasy and $10 \%$ for methamphetamine (21).

Alcohol is responsible for approximately one tenth of traffic accidents and one third of traffic injuries (22) in Germany and New Zealand (23) and a combination of other psychotropic drugs with alcohol increases the risk of a traffic accident (15). Driving under the influence of alcohol increases the risk for culpability in a traffic accident with blood alcohol concentrations of 1 $1.5 \mathrm{~g} / \mathrm{kg}$ by a factor of 4 (24). The magnitude of influence seems to be lower for illicit drugs (25), although an odds ratio 3.32 [95\%CI 2.63-4.18] for culpability for an accident was identified in drivers positively tested for cannabis compared with negative controls in a recent French study (26).

Death is the most severe consequence of traffic accidents. The impact of impaired driving on the mortality resulting from accidents has been described in a number of studies. Detection of alcohol and other drugs in deceased drivers is far more frequent than the prevalence found in field studies (road testing). Alcohol and other drugs in 33\% and 19\% was reported in Scotland (27), $17-24 \%$ and $6-8 \%$ was reported in Sweden. Alcohol was detected in $48 \%$, cannabis in $13 \%$, cocaine in $4 \%$ and benzodiazepines in $5 \%$ of fatal victims of traffic accidents in Canada (28). In France, at least $28.6 \%$ of fatal accidents were estimated to be attributable to alcohol, compared to $2.5 \%$ for cannabis (26).

This article describes the results of alcohol and other drug testing in deceased drivers and other deceased active participants in traffic accidents in the Czech Republic in 2003-2005; additionally, we discuss other data on alcohol and other drugs in road traffic. The preliminary results obtained from the previously performed similar analyses had already been published together with a detailed description of the methodology (29).

\section{MATERIAL AND METHODS}

A special mortality register has been fed with relevant data by all thirteen Czech departments of forensic medicine and forensic toxicology since 1998. Since then it has been used primarily for gathering and analysis of data on direct and indirect drug-related deaths (30-32). In general, the register records detailed data on all autopsies and related toxicology examinations that were carried out in these departments from the year stated above.

The studied sample consists of persons autopsied in the departments of forensic medicine and forensic toxicology who died during traffic accidents and were active participants in those accidents (i.e. pedestrians or those operating machines or bicycles involved in the accident - see below) and were toxicologically tested (i.e. tested for the presence of ethanol or at least some or all of the drugs belonging to the following groups: volatile substances, opiates, stimulants, cannabinoids, cocaine, benzodiazepines, barbiturates) in 2003-2005. ICD-10 codes for external causes of mortality and morbidity related to land transport accidents (V01-V89) were used for determination of participation in road traffic accidents.

As far as alcohol is concerned, cases with an alcohol level higher than $0.2 \mathrm{~g} / \mathrm{kg}$ are regarded as positive in the present study. This level is considered to be positive in accordance with the opinion of the Society of Forensic Medicine and Forensic Toxicology of the Czech Medical Association of J. E. Purkyně (33). As far as cannabis is concerned, positive cases involved those cases where THC or its active metabolite were found (THC-COOH positive findings alone were not regarded as "active-cannabinoids-positive”). Positive cases of volatile substances involved the detection of substances which do not develop post mortem and are not encountered in several physiological or pathological conditions (e.g. acetone, acetaldehyde, n-propanole, n-butanole). Blood alcohol level examinations were carried out according to the Guidelines for Ethanol Level Measurement issued by the Society of Forensic Medicine and Forensic Toxicology of the Czech Medical Association of J. E. Purkyně (34). The toxicological analysis ran mostly in accordance with Laboratory guidelines for toxicological analysis (35). At the minimum, toxicological analysis involved urine screening by means of immunochemical methods and confirmation by means of a specific analytic method after previous extraction from blood or organs. The main focus of such analyses was centered on pharmaceutical and other drugs.

All traffic accident deaths were divided into four categories: pedestrians, cyclists, drivers of motor vehicles (these three groups are considered as "active participants" in traffic accidents), and others. Active participants who have been toxicologically tested comprise our sample. The category "others” involves mainly copassengers in motor vehicles and passengers of public transport vehicles.

Statistical package SPSS v. 11.5 was used for the following analysis.

\section{RESULTS}

A total of 34,049 bodies were autopsied in the departments of forensic medicine and forensic toxicology in 2003-2005. Of these 3,337 (9.8\%) were victims of traffic accidents and 1,705 (51.1\%) of them were tested toxicologically (Table 1 ).

The sample of those toxicologically tested was divided into 4 groups: pedestrians, cyclists, drivers of motor vehicles and others (Table 2).

The sample of active participants is analyzed here. Of 1,213 cases, 1,039 (85.7\%) were males, and 174 (14.3\%) were females. The mean age of the sample was 42.4 years.

The highest proportion of positive results was found for ethanol with a significantly ( $<<0.01$ in Pearson $\chi^{2}$ test) declining trend over the years - from $39.8 \%$ in 2003 to $30.4 \%$ in 2005 among all active participants in traffic accidents, and from $32.0 \%$ to $18.7 \%$ among drivers. The proportion of positive detections for any psychotropic drug other than alcohol was $7.2 \%$ in our sample; the divergences in different years were statistically

Table 1. Overview of autopsies in forensic medicine departments in the Czech Republic in 2003-2005

\begin{tabular}{|l|c|c|c|}
\hline Year & $\begin{array}{c}\text { Total number of } \\
\text { dissected bodies }\end{array}$ & $\begin{array}{c}\text { Dead victims } \\
\text { of traffic accidents }\end{array}$ & $\begin{array}{c}\text { Toxicologically } \\
\text { tested }\end{array}$ \\
\hline $\mathbf{2 0 0 3}$ & 9,960 & 1,035 & 554 \\
\hline $\mathbf{2 0 0 4}$ & 12,731 & 1,255 & 589 \\
\hline $\mathbf{2 0 0 5}$ & 11,358 & 1,047 & 561 \\
\hline Total & 34,049 & 3,337 & 1,704 \\
\hline
\end{tabular}


Table 2. Toxicologically tested victims of traffic accidents by categories in 2003-2005

\begin{tabular}{|l|c|c|c|c|c|c|}
\hline \multirow{2}{*}{ Year } & \multicolumn{4}{|c|}{$\begin{array}{c}\text { Dead active participants } \\
\text { of traffic accidents }\end{array}$} & \multirow{2}{*}{ Others } & \multirow{2}{*}{ Total } \\
\cline { 2 - 6 } & Pedestrians & Cyclists & Drivers & Total & & \\
\hline $\mathbf{2 0 0 3}$ & 143 & 50 & 204 & 397 & 157 & 554 \\
\hline $\mathbf{2 0 0 4}$ & 154 & 44 & 219 & 417 & 172 & 589 \\
\hline $\mathbf{2 0 0 5}$ & 154 & 35 & 210 & 399 & 162 & 561 \\
\hline Total & 451 & 129 & 633 & 1,213 & 491 & 1,704 \\
\hline
\end{tabular}

insignificant (Pearson $\chi^{2}$ test). For psychotropic drugs other than alcohol, benzodiazepines were found most frequently (3.6\%), followed by cannabis (2.2\%), and stimulants (1.7\%) (Table 3). Methamphetamine and MDMA (ecstasy) were the only types of stimulants detected; no cases of either crack or powder cocaine or amphetamines (Benzedrine/Dexedrine) were found in the three years analyzed in this study.

Positive findings of ethanol were significantly more common among males than among females; on the other hand, benzodiazepines were detected much more frequently among females than among males. No gender difference was found in other drugs (Table 4).

The age of the positively tested dead active participants in traffic accidents was significantly lower than the age of negatively tested in the case of ethanol, volatile substances, stimulants, and cannabis. In medicaments positive cases were significantly older than negative cases. In other drugs no significant differences were observed (Table 5).

\section{DISCUSSION}

Our sample consisted of autopsied victims of traffic accidents who were toxicologically tested. According to these data, the frequency of drivers and other active participants under the influence of ethanol who end up dead because of the traffic accident they have been involved in is approximately ten times higher than the same indicator for all other psychotropic drugs combined. Of those drugs, cannabis and benzodiazepines are approximately 10 times more prevalent than other non-alcohol psychotropic drugs combined - i.e. opiates/opioides, methamphetamine and MDMA. Our results are very similar to the results of another study in 200 drivers deceased in the Southern Bohemia region during 1998-2002 (illicit drugs in 1.2\%, medical psychotropic drugs in 4.8, and ethanol in $37 \%$ of cases) (36).

Taking into account that drug and alcohol driving can aggravate the severity of injuries, the prevalence of impaired driving is probably lower than the one found in our study. Unfortunately, to date the only available field study in this respect is in the Czech Republic - ethanol was detected in 2,35\% of randomly checked drivers (37). Official Czech Police figures suggest that approximately $4.5 \%$ of traffic accidents were caused by active participant under the influence of ethanol and that less than $0.5 \%$ of drivers tested during field traffic operations were positive for ethanol (38-41). Official figures are probably underestimated, because the examination of deceased drivers is not always requested by police officers and special, one-off high-scale field operations have

Table 3. Detection of alcohol and narcotic and psychotropic substances among victims of traffic accidents

\begin{tabular}{|c|c|c|c|c|c|c|c|c|c|}
\hline & & Ped & ians & & & & & & \\
\hline Substan & & $\begin{array}{c}\text { Number } \\
\text { tested }\end{array}$ & $\begin{array}{c}\text { Positive } \\
(\%)\end{array}$ & $\begin{array}{c}\text { Number } \\
\text { tested }\end{array}$ & $\begin{array}{c}\text { Positive } \\
(\%)\end{array}$ & $\begin{array}{c}\text { Number } \\
\text { tested }\end{array}$ & $\begin{array}{c}\text { Positive } \\
(\%)\end{array}$ & $\begin{array}{c}\text { Number } \\
\text { tested }\end{array}$ & $\begin{array}{c}\text { Positive } \\
(\%)\end{array}$ \\
\hline & 2004 & 141 & 51.1 & 50 & 40.0 & 203 & 32.0 & 394 & 39.8 \\
\hline & 2004 & 150 & 48.7 & 44 & 29.5 & 209 & 23.9 & 403 & 33.7 \\
\hline Ellanol & 2005 & 148 & 45.3 & 35 & 34.3 & 198 & 18.7 & 381 & 30.4 \\
\hline & Total & 439 & 48.3 & 129 & 34.9 & 610 & 24.9 & 1,178 & 34.7 \\
\hline Volatile s & & 439 & 1.1 & 129 & 0.0 & 610 & 0.2 & 1,178 & 0.5 \\
\hline Opiates ( & & 304 & 0.0 & 68 & 2.9 & 474 & 0.4 & 846 & 0.5 \\
\hline $\begin{array}{l}\text { Stimulant } \\
\text { methamp }\end{array}$ & asy) & 303 & 1.7 & 67 & 0.0 & 470 & 1.9 & 840 & 1.7 \\
\hline Cocaine & & 134 & 0.0 & 31 & 0.0 & 200 & 0.0 & 365 & 0.0 \\
\hline $\begin{array}{l}\text { Cannabis } \\
\text { (THClact }\end{array}$ & $\mathrm{HC)}$ & 168 & 2.4 & 46 & 0.0 & 295 & 2.4 & 509 & 2.2 \\
\hline Benzodia & & 301 & 4.0 & 68 & 5.9 & 469 & 3.0 & 838 & 3.6 \\
\hline Barbitura & & 298 & 1.3 & 66 & 1.5 & 449 & 0.7 & 813 & 1.0 \\
\hline $\begin{array}{l}\text { Any of th } \\
\text { drugs oth }\end{array}$ & & 335 & 8.4 & 80 & 8.8 & 510 & 6.3 & 925 & 7.2 \\
\hline $\begin{array}{l}\text { Combina } \\
\text { and any }\end{array}$ & & 323 & 3.7 & 80 & 2.5 & 488 & 1.0 & 891 & 2.1 \\
\hline
\end{tabular}


Table 4. Positive detection of alcohol and other narcotic and psychotropic substances among victims of traffic accidents by gender

\begin{tabular}{|l|c|c|c|c|}
\hline \multirow{2}{*}{ Substance } & \multicolumn{2}{|c|}{ Males } & \multicolumn{2}{c|}{ Females } \\
\cline { 2 - 5 } & $\begin{array}{c}\text { Num. } \\
\text { tested }\end{array}$ & Positive (\%) & $\begin{array}{c}\text { Num. } \\
\text { tested }\end{array}$ & Positive (\%) \\
\hline Ethanol** & 1008 & 38.1 & 170 & 14.7 \\
\hline Volatile substances & 1008 & 0,5 & 170 & 0,6 \\
\hline Opiates (including heroin) & 731 & 0.3 & 115 & 1.7 \\
\hline $\begin{array}{l}\text { Stimulants } \\
\text { (including methampheta- } \\
\text { mine and ecstasy) }\end{array}$ & 726 & 1.7 & 114 & 1.8 \\
\hline Cocaine & 313 & 0.0 & 52 & 0.0 \\
\hline $\begin{array}{l}\text { Cannabis (THClactive } \\
\text { metabolites of THC }\end{array}$ & 443 & 2.5 & 66 & 0.0 \\
\hline Benzodiazepines & 724 & 2.9 & 114 & 7.9 \\
\hline Barbiturates & 702 & 0.9 & 111 & 1.8 \\
\hline
\end{tabular}

Note: * gender specific difference at significance level of $p<0.05$, ** gender specific difference at significance level of $p<0.01$ (Pearson $\chi^{2}$ test).

Table 5. Mean (median) age of toxicologically positive and negative participants in traffic accidents

\begin{tabular}{|l|c|c|}
\hline Substance & Positive & Negative \\
\hline Ethanol** & $40.1(38)$ & $44.2(42)$ \\
\hline Volatile substances & $28.6(25)$ & $42.8(41)$ \\
\hline Opiates (including heroin) & $37.3(37)$ & $40.2(37)$ \\
\hline $\begin{array}{l}\text { Stimulants } \\
\text { (including methamphetamine and ecstasy) }\end{array}$ & $27.4(22.5)$ & $40.4(37)$ \\
\hline Cocaine & - & $40.0(35)$ \\
\hline Cannabis (THClactive metabollites of THC)** & $21.2(20)$ & $37.8(33)$ \\
\hline Benzodiazepines & $46.5(44.5)$ & $40.1(37)$ \\
\hline Barbiturates & & \\
\hline
\end{tabular}

Note: * mean age difference at significance level of $p<0.05,{ }^{* *}$ mean age difference at significance level of $p<0.01$ (ANOVA test).

considerable publicity probably leading to increased awareness among drivers who subsequently might have a greater propensity to avoid drinking and the use of other psychotropic substances.

Recently, the Police of the Czech Republic have piloted so called “drug detection kits" using saliva or sweat specimens for the detection of drugs in drivers. This testing is expected to be extended and methodological guidelines will be completed after the evaluation of the pilot phase in 2007. Taking into account the relatively low prevalence of illegal and pharmaceutical drugs in drivers, the effectiveness (and particularly cost-effectiveness) of the broader introduction of "drug detection kits" is questionable; the introduction of field performance tests assessing and predicting driving performance seems to be a more adequate approach $(42,43)$. An obvious option would be, e.g., the procurement of training packages for the Standardised Field Sobriety Test (23, 30) or Drug Recognition Expert Assessment (42) for the Czech Traffic Police officers.
Our data indicate a statistically significant decrease of ethanol detection in deceased drivers; the reason for such a trend is not fully clear and the trend could only be confirmed in future follow up. One possible explanation for this positive trend is a change of attitude in Czech society related to the public debate on impaired driving linked with the amendment of The Road Traffic Act and several provisions of the Act on Misdemeanors and the Penal Code since 2006, which have increased penalties for impaired driving. Another explanation relates to more extensive police activities in drink-driving checks on drivers within the framework of the so-called traffic safety operations and also during regular checks in recent years targeting also sport-, cultural- and other social events (44).

Our results confirm a relatively high prevalence of medical drugs, especially benzodiazepines in Czech drivers. Preventative measures in this regard should be implemented; for example more noticeable warnings on patient package leaflets or on the labels of packages concerning the impairment of the ability to drive; it could also include symbols or pictograms (for instance, an exclamation mark or an exclamation mark in a triangle). However, these symbols are used rarely in the Czech Republic; in the Czech pharmaceutical market, explicit, effective warnings are missing even on packages of medicaments with clear considerable influence on psychomotor functions.

\section{REFERENCE}

1. Ogden EJ, Moskowitz H. Effects of alcohol and other drugs on driver performance. Traffic Inj Prev. 2004 Sep;5(3):185-98.

2. Drummer $\mathrm{OH}$, Odell $\mathrm{M}$. The forensic pharmacology of drugs of abuse. London: Arnold; 2001.

3. Vorel F. Influence of ethanol on the ability to drive a motor vehicle. Soud Lék. 2003;48(1):5-7.

4. Ramaekers JG, Robbe HW, O’Hanlon JF. Marijuana, alcohol and actual driving performance. Hum Psychopharmacol. 2000 Oct;15(7):551-8.

5. Walsh JM, de Gier JJ, Christopherson AS, Verstraete AG. Drugs and driving. Traffic Inj Prev. 2004 Sep;5(3):241-53.

6. Papafotiou K, Carter JD, Stough C. The relationship between performance on the standardised field sobriety tests, driving performance and the level of Delta9-tetrahydrocannabinol (THC) in blood. Forensic Sci Int. 2005 Dec 20;155(2-3):172-8.

7. Raes E, Verstraete AG. Cannabis and driving: the situation in Europe. Ann Pharm Fr. 2006 May;64(3):197-203. (In French.)

8. Ramaekers JG, Moeller MR, van Ruitenbeek P, Theunissen EL, Schneider E, Kauert G. Cognition and motor control as a function of Delta9-THC concentration in serum and oral fluid: limits of impairment. Drug Alcohol Depend. 2006 Nov 8;85(2):114-22.

9. Khiabani HZ, Bramness JG, Bjorneboe A, Morland J. Relationship between THC concentration in blood and impairment in apprehended drivers. Traffic Inj Prev. 2006 Jun;7(2):111-6.

10. Brookhuis KA, de Waard D, Samyn N. Effects of MDMA (ecstasy), and multiple drugs use on (simulated) driving performance and traffic safety. Psychopharmacology (Berl). 2004 May;173(3-4):440-5.

11. Brunnauer A, Laux G. Driving capacity and antidepressive drugs. Psychiatr Prax. 2003 May;30 Suppl 2:S102-5. (In German.)

12. Morike K, Gleiter ChH. Medicinal drugs and automobile driving ability. Ther Umsch. 2003 Jun;60(6):347-54. (In German.)

13. The Pompidou Group. Road traffic and psychoactive substances. Proceedings; 2003 Jun 18-20; Strasbourg. Strasbourg: Council of Europe; 2004.

14. Caetano R, McGrath C. Driving under the influence (DUI) among U.S. ethnic groups. Accid Anal Prev. 2005 Mar;37(2):217-24.

15. Kelly E, Darke S, Ross J. A review of drug use and driving: epidemiology, impairment, risk factors and risk perceptions. Drug Alcohol Rev. 2004 Sep;23(3):319-44. 
16. Dussault C, Brault M, Bouchard J, Lemire AM. The contribution of alcohol and other drugs among fatally injured drivers in Québec: some preliminary results. In: Mayhew DR, Dussault C, editors. Proceedings of the 16th International Conference on Alcohol, Drugs and Traffic Safety; 2002 Aug 4-9; Montreal. Québec: Société de l’assurance automobile du Québec; 2002. p. 423-30.

17. Asbridge M, Poulin C, Donato A. Motor vehicle collision risk and driving under the influence of cannabis: evidence from adolescents in Atlantic Canada. Accid Anal Prev. 2005 Nov;37(6):1025-34.

18. Riley SC, James C, Gregory D, Dingle H, Cadger M. Patterns of recreational drug use at dance events in Edinburgh, Scotland. Addiction. 2001 Jul;96(7):1035-47.

19. Albery IP, Strang J, Gossop M, Griffiths P. Illicit drugs and driving: prevalence, beliefs and accident involvement among a cohort of current out-of-treatment drug users. Drug Alcohol Depend. 2000 Feb 1;58(12):197-204.

20. Darke S, Kelly E, Ross J. Drug driving among injecting drug users in Sydney, Australia: prevalence, risk factors and risk perceptions. Addiction. 2004 Feb;99(2):175-85.

21. Kubů P, Škařupová K, Csémy L. Dancing and drugs 2000 and 2003: results of a questionnaire survey. Prague: Office of the Government; 2006. (In Czech.)

22. Kruger HP, Vollrath M. The alcohol - related accident risk in Germany: procedure, methods and results. Accid Anal Prev. 2004 Jan;36(1):12533.

23. Connor J, Norton R, Ameratunga S, Jackson R. The contribution of alcohol to serious car crash injuries. Epidemiology. 2004 May;15(3):337-44.

24. Drummer OH, Gerostamoulos J, Batziris H, Chu M, Caplehorn J, Robertson MD, et al. The involvement of drugs in drivers of motor vehicles killed in Australian road traffic crashes. Accid Anal Prev. 2004 Mar;36(2):239-48.

25. Longo MC, Hunter CE, Lokan RJ, White JM, White MA. The prevalence of alcohol, cannabinoids, benzodiazepines and stimulants amongst injured drivers and their role in driver culpability: part ii: the relationship between drug prevalence and drug concentration, and driver culpability. Accid Anal Prev. 2000 Sep;32(5):623-32.

26. Laumon B, Gadegbeku B, Martin JL, Biecheler MB; SAM Group. Cannabis intoxication and fatal road crashes in France: population based case-control study. BMJ. 2005 Dec 10;331(7529):1371. Erratum in: BMJ. 2006 Jun 3;332(7553):1298.

27. Seymour A, Oliver JS. Role of drugs and alcohol in impaired drivers and fatally injured drivers in the Strathclyde police region of Scotland, 1995-1998. Forensic Sci Int. 1999 Jul 26;103(2):89-100

28. Mercer GW, Jeffery WK. Alcohol, drugs, and impairment in fatal traffic accidents in British Columbia. Accid Anal Prev. 1995 Jun;27(3):33543.

29. Mravčík V, Zábranský T, Vorel F. Psychotropic substances and traffic accidents. Čas Lék Čes. 2005;144(8):550-5. (In Czech.)
30. Zábranský T, Vorel F. Estimate of drug-related deaths in the Czech Republic: pilot phase (1998). Adiktologie. 2001;1(2):9-26. (In Czech.)

31. Zábranský T, Vorel F, Balíková M, Šejvl J. Lethal overdosage with illegal drugs and volatile substances in the Czech Republic. Brief review and manual for monitoring. Prague: Office of the Government; 2004. (In Czech.)

32. Mravčík V, Lejčková P, Orlíková B, Petrošová B, Škrdlantová E, Trojáčková A, et al. Annual report on the state of the drug issue in the Czech Republic in 2005. Prague: Office of the Government; 2006. (In Czech.)

33. Society for Forensic Medicine and Forensic Toxicology. Standpoint of the Society for Forensic Medicine and Forensic Toxicology on problems of calculating the concentration of ethanol in blood. Soud Lék. 1999;4(4):55. (In Czech.)

34. Society for Forensic Medicine and Forensic Toxicology. Instructions on ethanol determination from the Society for Forensic Medicine and Forensic Toxicology. Soud Lék. 1998;43(3):46. (In Czech.)

35. de Zeeuw RA, et al. Laboratory guidelines for toxicological analysis. Bull Int Assoc Forensic Toxicologists. 2001;31(4):423-6.

36. Vorel F. Mortality of drivers over the years 1998-2002. České Budějovice: 2003. (In Czech.) Notes: Unpublished

37. Vorel F. The Proportion of drivers with alcohol in blood in a common traffic. Soud Lék. 2004;49(3):38-42. (In Czech.)

38. Directorate of Traffic Police Services of the Police Presidium of the Czech Republic. The accident rate on surface communications in the Czech Republic in 2003. Prague: Ministry of Interior; 2004. (In Czech.)

39. Directorate of Traffic Police Services of the Police Presidium of the Czech Republic. Results of the campaign „, Christophor“ over the years 2003-2006. Prague: Ministry of Interior; 2006. (In Czech.)

40. Directorate of Traffic Police Services of the Police Presidium of the Czech Republic. The accident rate on surface communications in the Czech Republic in 2004. Prague: Ministry of Interior; 2005. (In Czech.)

41. Directorate of Traffic Police Services of the Police Presidium of the Czech Republic. The accident rate on surface communications in the Czech Republic in 2005. Prague: Ministry of Interior; 2006. (In Czech.)

42. Adler EV, Burns M. Drug Recognition Expert (DRE) validation study. Final report. Phoenix: Arizona Governor's Office of Highway Safety; 1994.

43. Stough C, Boorman M, Ogden E, Papafotiou K. An evaluation of the Standardised Field Sobriety Tests for the detection of impairment associated with cannabis with and without alcohol. Payneham, South Australia: National Drug Law Enforcement Research Fund; 2006.

44. Ministry of Transport. The national strategy of safe road traffic - information on fulfilling in 2005. Prague: Ministry of Transport; 2006. (In Czech.)

Received April 10, 2007 Accepted June 21, 2007 